\title{
Studi Kualitas Air Reverse Osmosis Secara Mikrobiologi pada Dua Unit Hemodialisis di Kota Bandung
}

\author{
Adi Imam Cahyadi, ${ }^{1}$ Rovina Ruslami, ${ }^{2}$ Sunaryati Sudigdoadi ${ }^{1}$ \\ ${ }^{1}$ Departemen Mikrobiologi dan Parasitologi Fakultas Kedokteran Universitas Padjadjaran \\ ${ }^{2}$ Departemen Farmakologi Fakultas Kedokteran Universitas Padjadjaran
}

\begin{abstract}
Abstrak
Kontaminasi bakteri pada air reverse osmosis (RO) yang digunakan untuk hemodialisis (HD) dapat menyebabkan respon inflamasi, termasuk inflamasi kronis. Pasien HD memiliki risiko kematian yang tinggi akibat kejadian kardiovaskular yang berkaitan erat dengan inflamasi kronis. Penelitian ini bertujuan untuk mengetahui gambaran kualitas air RO dan jenis bakteri kontaminan pada saluran distribusi unit HD di Kota Bandung secara mikrobiologi. Enam belas sampel air diambil dari unit HD di dua rumah sakit (RS) pada bulan September 2014, sebelas sampel dari unit HD di RS A dan lima dari unit HD di RS B, secara langsung pada titik sebelum dan sesudah proses RO. Sampel air diinokulasi pada Reasoner's agar (R2A), koloni bakteri yang tumbuh kemudian diisolasi dan diidentifikasi di laboratorium Mikrobiologi Rumah Sakit Pendidikan (RSP) Unpad. Sampel air dari RS A menunjukkan pertumbuhan koloni bakteri 213-1473 cfu/mL. Sampel dari RS B menunjukkan pertumbuhan koloni 0-99 $\mathrm{cfu} / \mathrm{mL}$. Pada identifikasi didapatkan 12 spesies bakteri yang terdiri dari 8 spesies batang gram negatif, 3 spesies kokus gram positif, dan 1 spesies batang gram positif. Kualitas air RO unit HD RS A masih rendah karena hitung koloni yang tinggi dan perlu segera diperbaiki, pada RS B masih dalam batas yang diperbolehkan.
\end{abstract}

Kata kunci: Hemodialisis, Kontaminasi Bakteri, Reverse Osmosis

\section{Reverse Osmosis Water Microbiological Quality Study in Hemodialysis Unit in Bandung}

\begin{abstract}
Bacterial contamination of water reverse osmosis (RO) is used for hemodialysis (HD) can induce inflammatory responses, including chronic inflammation. HD patients have a high risk of death due to cardiovascular events, which are strongly associated with chronic inflammation. This study aims to reveal the RO water microbiological quality and type of bacterial contaminants in the HD unit distribution system in two hospitals in Bandung City. Sixteen water samples were taken from the HD units in September 2014, eleven samples at hospital A and five in hospital $B$, directly at the point before and after the RO process. Water samples were inoculated on Reasoner's agar (R2A), grown colonies of bacteria were then isolated and identified at Microbiology laboratory, Unpad Teaching Hospital. Water samples from hospital A showed a range of bacterial growth of $213-1473 \mathrm{cfu} / \mathrm{mL}$. Samples from the hospital B showed colony growth of 0-99 cfu/mL. The identification of 12 species of bacteria obtained consist of 8 species of gram-negative rods, three species of gram-positive cocci, and one species of gram-positive rods. $R O$ water quality in HD unit $A$ are low due to high colony count and needs to be repaired. RO water quality in HD unit B are still under the maximum level permitted. Based on the different results for the two hospitals, it is advisable that all HD units using $R O$ water, be checked regularly for bacterial contaminants
\end{abstract}

Keywords: Bacterial Contamination, Hemodialysis, Reverse Osmosis

Korespondensi:

Adi Imam Cahyadi, dr., M.Kes

Departemen Mikrobiologi dan Parasitologi ,Fakultas Kedokteran Universitas Padjadjaran

Jl. Prof. Dr. Eyckman No. 38 Bandung 40161

Mobile : 08157005856

Email : adi.imam@unpad.ac.id 


\section{Pendahuluan}

Pasien hemodialisis (HD) mengalami risiko yang merugikan dari penggunaan air yang digunakan dalam proses HD. Setiap pasien yang menjalani HD dua kali seminggu akan terpapar air hingga 16.000 Liter (L) dalam setahun, bahkan dapat mencapai 24.000 L bila menjalani HD tiga kali seminggu. Oleh karena itu kualitas air yang baik mutlak diperlukan, tidak saja untuk keselamatan pasien, bahkan dapat menunjang tercapainya HD yang adekuat. ${ }^{1}$ Kualitas air secara mikrobiologi menurut standard ISO 11663 tahun 2014 adalah kandungan maksimal mikroorganisme $100 \mathrm{cfu} /$ $\mathrm{mL}$ (cfu=colony forming unit) dan endotoksin $0,25 \mathrm{EU} / \mathrm{mL}$ (EU=endotoxin unit) dengan level aksi pada $50 \mathrm{cfu} / \mathrm{mL}$ dan $0,125 \mathrm{EU} / \mathrm{mL}$. $^{2}$

Kontaminasi bakteri merupakan masalah yang paling sulit untuk ditanggulangi. Dari hasil temuan di dua tempat yang berbeda di Brazil, kontaminasi bakteri masih ditemukan pada saluran distribusi air RO untuk HD, bahkan beberapa di antaranya berpotensi mengandung bakteri patogen seperti Pseudomonas aeruginosa, Bacillus subtilis, dan Burkholderia cepacia. ${ }^{3,4}$ Hal ini membuktikan bahwa bakteri memiliki kemampuan untuk beradaptasi pada keadaan rendah nutrisi dan bertahan hidup. ${ }^{5}$

Bakteri secara utuh memang tidak dapat melewati membran dialiser untuk memasuki tubuh pasien, namun tetap berpotensi bahaya bila terjadi kondisi pada membran dialiser tidak intak, atau akibat produk-produk biologis yang dihasilkan oleh bakteri. ${ }^{6,7}$ Fragmen yang dilepaskan seperti endotoksin, muramilpeptida, dan polisakarida, dapat melintasi membran dialisis. ${ }^{6,7}$ Penelitian yang dilakukan secara in vitro oleh Weber dkk. membuktikan bahwa pirogen yang dihasilkan oleh bakteri mampu melewati membran dialiser, bahkan pada jenis membran low flux sekalipun. ${ }^{6}$ Pasien yang terpapar senyawa yang sudah terkontaminasi tersebut dapat mengalami dampak langsung dalam bentuk reaksi pirogenik, dan apabila paparan berlangsung dalam periode yang relatif lebih lama, fragmen endotoksin dan DNA bakteri dapat menyebabkan timbulnya inflamasi kronis. ${ }^{6,8-10}$

Inflamasi kronis pada pasien HD berkaitan erat dengan status gizi yang buruk dan risiko kematian yang tinggi akibat kejadian kardiovaskuler, terutama aterosklerosis. ${ }^{11-13}$ Hubungan antara status nutrisi yang buruk, inflamasi yang terus berlangsung dan arterosklerosis pada pasien dialisis ini dikenal sebagai malnutritioninflamation-artherosclerosis (MIA) syndrome. ${ }^{13,14}$

Penderita gagal ginjal terminal semakin meningkatjumlahnya; diAmerika pada tahun 2009 diperkirakan terdapat 116.395 orang penderita gagal ginjal terminal yang baru. Data dari United State Renal Data System (USRDS) tahun 2011 menunjukkan lebih dari 380.000 penderita gagal ginjal terminal menjalani HD reguler.15 Menurut Indonesian Renal Registry (IRR), jumlah pasien baru dan pasien rutin HD selalu meningkat setiap tahun, diiringi dengan peningkatan jumlah unit pelayanan HD. Pada tahun 2011 di Indonesia terdapat 15.353 pasien baru HD dan pada tahun 2012 terjadi peningkatan sebanyak 4.268 orang sehingga secara keseluruhan ada 19.621 pasien baru. Sampai akhir tahun 2012 terdapat 244 unit HD di Indonesia, 46 diantaranya berlokasi di Jawa Barat. ${ }^{16}$ Sejak diimplementasikannya Jaminan Kesehatan Nasional (JKN) pada awal tahun 2014, HD termasuk dalam daftar tindakan yang dijamin dalam JKN, maka jumlah ini diyakini akan semakin meningkat. ${ }^{17}$

Semakin meningkat jumlah pasien HD dan tingginya risiko kematian akibat kejadian kardiovaskular memiliki kaitan yang erat dengan inflamasi kronis pada pasien HD memotivasi penulis untuk melakukan penelitian tentang gambaran kualitas air RO dan jenis bakteri kontaminan pada saluran distribusi unit HD di Kota Bandung secara mikrobiologi.

\section{Metode}

Penelitian ini bersifat penelitian deskriptif laboratoris, menggunakan air yang diambil dari saluran distribusi air RO sebagai obyek penelitian. Penelitian ini telah mendapatkan persetujuan etik yang dikeluarkan oleh Komite Etik Penelitian Kesehatan (KEPK) di Bandung pada tanggal 9 Mei 2014 dengan no. 208/ UN6.C2.1.2/KEPK/PN/2014. Sampel air RO diperoleh dari dua rumah sakit yang memiliki unit HD di Kota Bandung. Pada masing-masing rumah sakit, ditentukan titik-titik pengambilan sampel air sesuai dengan panduan dari Northwest Renal Network. ${ }^{18}$ Penelitian dilakukan pada bulan September hingga bulan Desember 2014, dengan pengambilan sampel air dilakukan pada bulan September 2014. Pemeriksaan secara mikrobiologi dilakukan di laboratorium mikrobiologi Rumah Sakit Pendidikan (RSP) Unpad. Adapun yang menjadi kriteria inklusi pada penelitian ini adalah fasilitas hemodialisis yang terintegrasi dalam rumah sakit, Fasilitas menggunakan purified water (RO) untuk hemodialisis yang sudah layak untuk digunakan, dinyatakanolehDinasKesehatanKota/Kabupaten, Fasilitas sudah secara rutin menyelenggarakan pelayanan hemodialisis, Sedangkan yang menjadi kriteria eksklusi adalah fasilitas tidak memiliki port untuk pengambilan sampel air RO. 
Pengambilan Sampel Air RO, Sampel diambil menggunakan teknik clean catch untuk meminimalkan potensi kontaminasi sampel, pada titik-titik berikut dalam Gambar 1.

Titik 1 pada titik di mana air keluar dari mesin RO, sebelum memasuki tangki penampungan (sistem tidak langsung), atau sebelum masuk ke dalam sistem distribusi air untuk mesin dialisis (sistem langsung). Titik 2 jika terdapat tangki penampungan air $\mathrm{RO}$, sampel harus diambil pada titik di mana air meninggalkan tangki, Titik 3 pada akhir sistem distribusi air, apakah itu kembali ke RO atau tangki air RO. Jika terdapat filter bakteri di dalam sistem distribusi, maka sampel diambil pada sebelum dan sesudah filter, Titik 4 pada titik di mana air masuk ke dalam sistem dialyzer reprocessing, baik sistem manual ataupun otomatis, Titik 5 Pada suatu titik di mana air masuk sistem persiapan cairan dialisis (konsentrat bikarbonat dan asam), Titik 6 pada titik di mana mesin dialisis dihubungkan ke saluran distribusi air RO, Titik 7 jika terdapat fasilitas penampungan air dengan deklorinasi dan softened sebagai cadangan, maka perlu untuk melakukan kultur dan uji limulus amebocyte lysate (LAL) pada air ini, karena RO adalah sumber utama perlindungan pasien dari bakteri. Deteksi bakteri kontaminan air RO dilakukan dengan inokulasi sampel pada agar Reasoner's
2A(R2A) menggunakan teknik tuang (pour plate) dan diinkubasi. Setelah diinkubasi, selanjutnya dilakukan penghitungan jumlah pertumbuhan koloni, isolasi, dan identifikasi bakteri. ${ }^{19}$ Inokulasi Bakteri Kontaminan, Agar R2A dipersiapkan dan disterilkan denganmenggunakan autoklaf selama 15 menit pada suhu $121^{\circ} \mathrm{C}$ pada hari sebelum pemeriksaan. Agar kemudian dipanaskan hingga mencair, lalu didinginkan kembali. Pada saat agar sudah mulai tidak terlalu panas dan belum memadat $\left(+45^{\circ} \mathrm{C}\right)$, agar dituang kedalam cawan petri dan ditambahkan dengan $1 \mathrm{~mL}$ sampel air RO. Cawan kemudian digoyang dengan gerakan memutar sebanyak 3 putaran dengan hati-hati. Cawan kemudian diinkubasi pada suhu $37^{\circ} \mathrm{C}$ selama 48 jam. ${ }^{17}$ Identifikasi Bakteri Kontaminan, Pada koloni yang tumbuh pada agar R2A, dilakukan langkahlangkah identifikasi bakteri yaitu: pewarnaan Gram, subkultivasi koloni yang tumbuh pada agar darah dan agar MacConkey No.3 untuk memisahkan bakteri Gram positif dan bakteri Gram negatif, dan kemudian dilanjutkan dengan uji biokimia yang diperlukan seperti: uji katalase, uji koagulase, uji KIA (Kligler's iron agar), uji MIU (motility, indole, urease), dan uji sitrat. Hasil yang didapat kemudian disesuaikan dengan diagram alur pada Bergey's manual untuk identifikasi. ${ }^{17}$

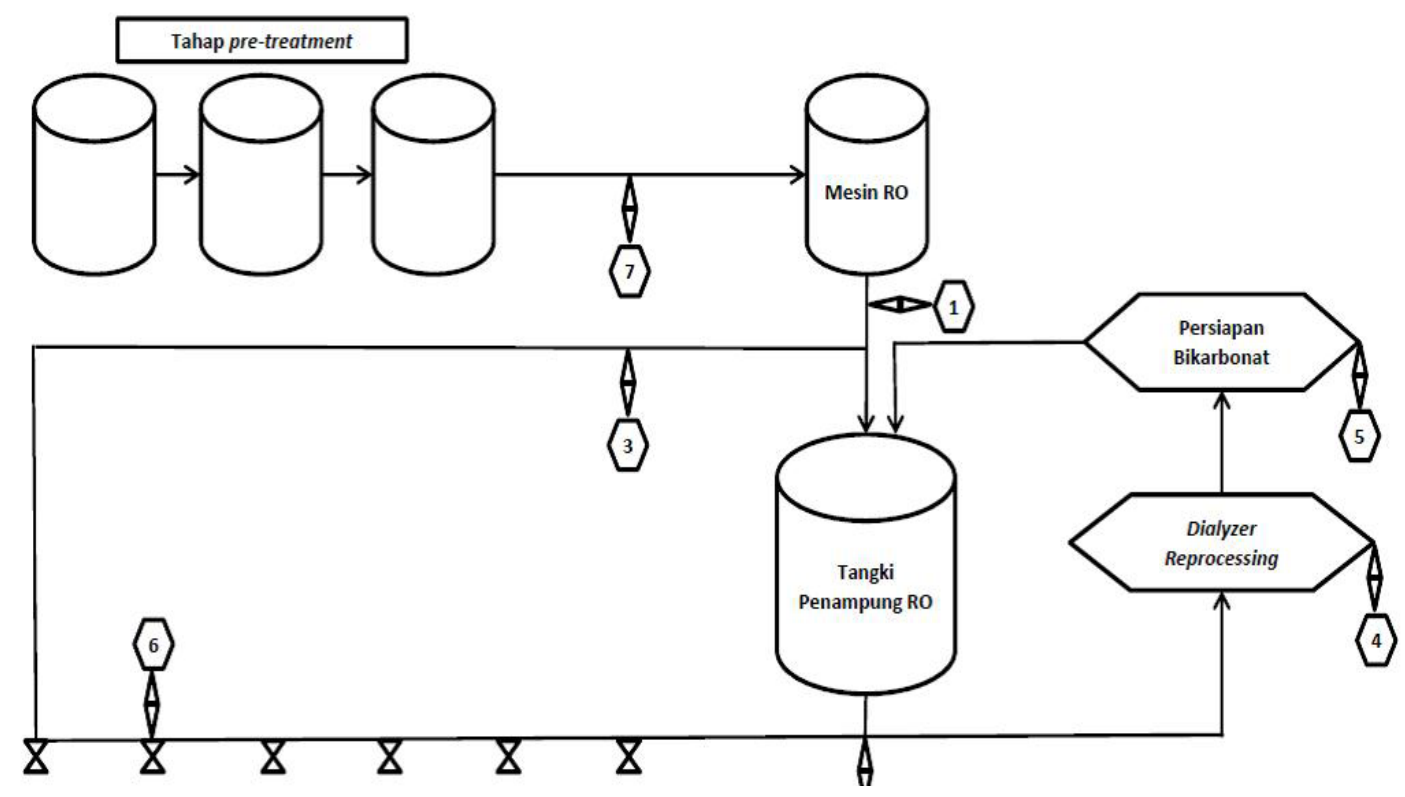

Gambar 1 Skema Unit Hemodialisis dan Lokasi Titik Pengambilan Sampel 


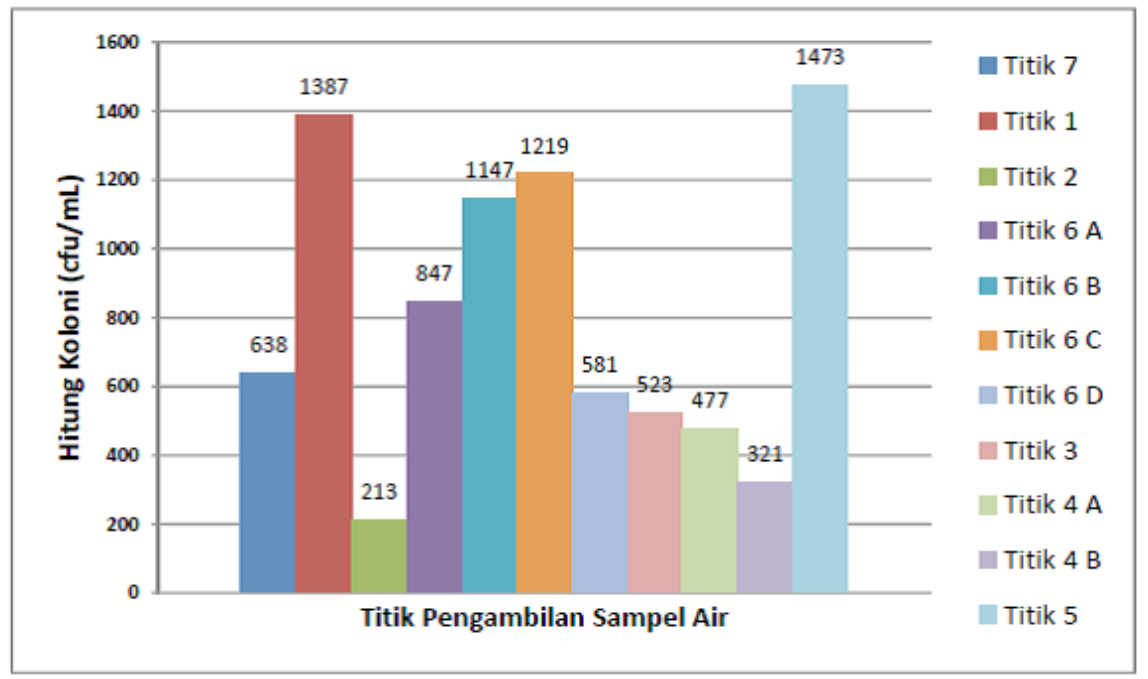

Gambar 2 Grafik hitung koloni bakteri kontaminan unit HD RS A pada medium R2A.

\section{Hasil}

Pada unit HD rumah sakit $\mathrm{A}$ diperoleh 11 titik sampel, pada unit HD rumah sakit B diperoleh 5 titik sampel. Pada setiap sampel dilakukan pemeriksaan secara mikrobiologis dengan cara dilakukan penanaman pada agar R2A, dilakukan hitung koloni bakteri, dan identifikasi bakteri.

Penelitian dilakukan secara makroskopis, mikroskopis, dan uji biokimia. Pengamatan secara makroskopis dilakukan terhadap pertumbuhan koloni bakteri pada agar R2A, pengamatan secara mikroskopis dan uji biokimia dilakukan dalam tahapan isolasi dan identifikasi bakteri. Pada Unit HD Rumah sakit A (RS A), hasil penghitungan jumlah koloni pertumbuhan bakteri di medium R2A, didapatkan jumlah tertinggi
$1473 \mathrm{cfu} / \mathrm{mL}$ pada titik 5 dan terendah $213 \mathrm{cfu} /$ $\mathrm{mL}$ pada titik 2 (gambar 2). Jumlah pertumbuhan koloni pada seluruh titik pengambilan sampel air berada diatas batas yang diperbolehkan (100 $\mathrm{cfu} / \mathrm{mL}$ ), bahkan pada titik setelah proses RO memperlihatkan angka pertumbuhan yang sangat tinggi. Dari medium dengan koloni yang memiliki perbedaan morfologi, diambil sampel untuk diisolasi. Proses berikutnya adalah melakukan identifikasi bakteri. Pemilihan koloni yang akan diisolasi dan diidentifikasi dilakukan berdasarkan pertimbangan morfologi koloni yang tumbuh. Hasil isolasi dan identifikasi bakteri dapat terlihat pada tabel 1. Dari total 34 isolat yang diperoleh dari 11 titik pengambilan sampel yang berbeda, dapat diidentifikasi 12 spesies/genus bakteri. Hal ini menunjukkan keberagaman spesies bakteri

Tabel 1 Hasil Isolasi dan Identifikasi Bakteri Kontaminan yang Tumbuh pada Medium R2A.

\begin{tabular}{cl}
\hline $\begin{array}{c}\text { Titik Pengambilan } \\
\text { Sampel }\end{array}$ & \multicolumn{1}{c}{ Spesies Bakteri Kontaminan } \\
\hline 7 & Citrobacter diversus Acinetobacter spp Serratia spp \\
1 & Klebsiella pnemoniae Staphylococcus saphrophyticus Micrococcus luteus \\
& Pseudomonas spp Acinetobacter spp \\
2 & Bacillus spp Micrococcus luteus \\
6A & Pseudomonas spp Enterobacter aerogenes \\
6B & Yersinia pseudotuberculosis Micrococcus luteus \\
6C & Bacillus spp Acinetobacter spp \\
6D & Pseudomonas spp Acinetobacter spp Micrococcus luteus \\
3 & Staphylococcus epidermidis Yersinia pseudotuberculosis \\
4A & Moraxella spp \\
4B & Micrococcus luteus Enterobacter aerogenes \\
5 & Citrobacter diversus \\
\hline
\end{tabular}




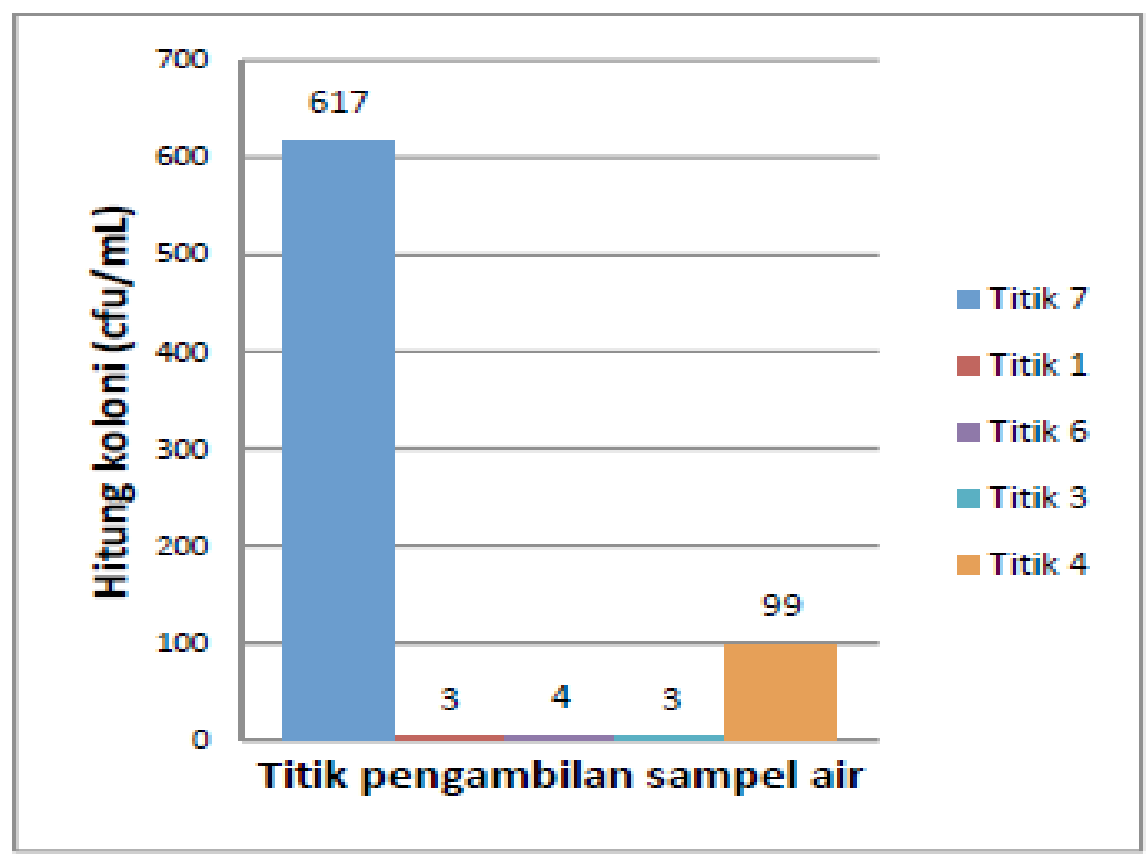

\section{Gambar 3 Grafik Perhitungan Koloni Pertumbuhan Bakteri Kontaminan Unit HD RS B pada Medium R2A.}

pada setiap bagian saluran air dapat saling berbeda. Semua sampel air di titik -titik pengambilan sesudah air keluar dari unit RO mengandung bakteri yang berbeda dengan sampel air sebelum masuk unit RO, kecuali Acinetobacter spp. Hasil pada Unit HD Rumah Sakit B (RS B) Pertumbuhan koloni bakteri terlihat pada seluruh sampel air RO dengan jumlah hitung koloni dibawah $100 \mathrm{cfu} / \mathrm{mL}$ (kecuali titik 7) yang merupakan batas yang diperbolehkan menurut standar ISO 11663 tahun 2014 (gambar 3).

Dari 4 isolat yang berhasil diisolasi, didapatkan 3 spesies bakteri kontaminan dari titik pengambilan sampel yang berbeda, $P$. aeruginosa menjadi kontaminan yang didapatkan pada titik sebelum dan sesudah proses RO (tabel 2). Pada sampel dari titik 1 dan titik 6 tidak dapat dilakukan isolasi dan identifikasi karena jumlah koloni yang sedikit dan letak pertumbuhan koloni yang tidak pada permukaan agar sehingga menyulitkan pada saat pengambilan koloni. Pada sebagian sampel koloni dari titik 4 juga tidak tumbuh pada saat dilakukan isolasi.

\section{Pembahasan}

Hasil yang didapatkan oleh peneliti menunjukkan bahwa terdapat kontaminasi bakteri pada saluran distribusi air RO di dua unit HD di Bandung. Kontaminasi tersebut berada diatas batas aman $(100 \mathrm{cfu} / \mathrm{mL})$ dan hal ini sangat mengkhawatirkan. Adanya bakteri kontaminan dapat berpotensi menimbulkan dampak yang merugikan pada pasien HD kronik, baik jangka pendek maupun jangka panjang. ${ }^{1}$ Sepanjang pengetahuan peneliti,

Tabel 2 Hasil Isolasi dan Identifikasi Bakteri Kontaminan yang Tumbuh pada Medium R2A.

\begin{tabular}{cl}
\hline Titik Pengambilan Sampel & Spesies Bakteri Kontaminan \\
\hline 7 & Pseudomonas spp \\
1 & Tidak dapat didentifikasi \\
6 & Tidak dapat diidentifikasi \\
3 & Bacillus spp Pseudomonas spp \\
4 & Yersinia pseudotuberculosis \\
\hline
\end{tabular}


ini adalah laporan yang pertama kali mengenai kualitas air RO unit pelayanan HD di Indonesia.

Tingginya tingkat kontaminasi pada saluran distribusi RO di rumah sakit A memperlihatkan bahwa kualitas air RO pada rumah sakit tersebut secara mikrobiologis adalah rendah. Tingkat kontaminasi bakteri yang terdapat pada RS A jauh melewati batas aman yang diperbolehkan. ${ }^{2}$ Sedangkan tingkat kontaminasi pada saluran distribusi RO rumah sakit B berada dalam batas toleransi, mengindikasikan bahwa kualitas air RO secara mikrobiologis di RS B adalah baik. Hitung koloni yang tinggi pada sampel air yang diambil pada titik 7 tidak menjadi masalah karena merupakan titik sebelum masuk proses pemurnian air (RO).

Tingginya tingkat kontaminasi pada saluran distribusi RO dapat menimbulkan dampak merugikan pada pasien yang menjalani HD. ${ }^{1}$ Dampak yang dapat timbul antara lain reaksi pirogenik, berupa menggigil atau panas badan selama tindakan HD. ${ }^{7}$ Dampak lain adalah terjadinya proses inflamasi kronis dalam tubuh pasien. Hal ini terjadi akibat tingginya tingkat kontaminasi yang menyebabkan tingginya produk bakteri yang beredar dalam air RO dan dapat masuk ke dalam tubuh pasien melewati membran dialiser. ${ }^{6,7}$ Penelitian ini memfokuskan kepada kualitas air RO pada unit HD, tidak menelusuri dampak yang terjadi pada pasien yang menjalani HD di unit tersebut.

Inflamasi kronis pada pasien HD merupakan awal mata rantai permasalahan atau penyulit yang muncul pada pasien HD kronis. ${ }^{9}$ Fragmen endotoksin dan DNA bakteri dapat memicu reseptor spesifik (CD14, TLR 2, dan TLR 8) pada mononuclear cells (MNC) yang menginduksi reaksi enzimatik. ${ }^{20}$ Reaksi tersebut kemudian mengaktifkan faktor-faktor transkripsi (NF$\kappa \mathrm{B}$, NF-IL-6, dll), yang dapat menghasilkan diantaranya nitrogen monoxide (NO), faktorfaktor koagulasi, prostaglandin, dan terutama sitokin-sitokin proinflamasi (IL-1 $\beta$, TNF- $\alpha$ dan TNF- $\beta$ ). ${ }^{10,20}$ Produk-produk tersebut dapat menimbulkan respon inflamasi, yang ditandai dengan adanya peningkatan kadar sitokin atau $C$ reactive protein (CRP). ${ }^{9,10}$ Adanya inflamasi kronis meningkatkan risiko terjadinya malnutrisi, anemia, atherosklesosis, kejadian penyakitjantung koroner, dan kematian akibat kardiovaskular pada pasien HD hingga 10-20 kali lebih besar dibandingkan pada populasi normal. ${ }^{11-14}$

Tingkat kontaminasi dapat dipengaruhi oleh beberapa faktor, antara lain frekuensi disinfeksi, jenis dan konsentrasi disinfektan yang digunakan, jenis dan usia pipa yang digunakan pada instalasi, frekuensi penggantian filter $\mathrm{RO}$, dan panjang pipa pada saluran keluar menuju mesin HD. ${ }^{3,4}$ Tingkat kontaminasi yang sangat tinggi pada unit HD RS A bahkan didapatkan pada titik dimana air RO baru saja mengalami proses pemurnian RO. Hal ini dapat mengindikasikan kurang efektifnya fungsi membran RO dalam memurnikan air, kurang efektifnya proses disinfeksi yang telah dilakukan, dan umur pipa saluran yang sudah terlalu lama dan perlu diganti. Kontaminasi yang sangat tinggi juga didapatkan pada titik 5 yang merupakan titik untuk persiapan cairan bikarbonat, dimana cairan bikarbonat adalah salah satu elemen penting yang digunakan dalam proses HD. Kontaminasi yang tinggi pada cairan bikarbonat dapat berdampak buruk pada pasien yang menjalani HD, dampak dapat berupa reaksi pirogenik hingga inflamasi kronis.

Tingginya tingkat kontaminasi pada RS A perlu mendapat perhatian khusus, terutama pada aspek pemeliharaan sistem pemurnian air dan saluran distibusi air RO. Perlu dilakukan evaluasi seperti efektivitas prosedur disinfeksi, frekuensi disinfeksi, jenis disinfektan yang digunakan, frekuensi penggantian filter $\mathrm{RO}$, dan panjang pipa outlet ke mesin HD. Apabila telah dilakukan seluruh langkah evaluasi dan masih didapatkan tingkat kontaminasi yang tinggi, maka perlu dilakukan penggantian pipa instalasi air RO. ${ }^{18}$

Pada studi ini didapatkan 12 spesies bakteri kontaminan pada unit HD RS A dan 3 spesies pada unit HD RS B. Bakteri kontaminan yang didapat pada unit HD RS A terdiri dari 8 spesies batang Gram negatif (K. pneumoniae, E. aerogenes, Y. pseudotuberculosis, $C$. diversus, Moraxella spp, Acinetobacter spp, Pseudomonas spp, dan Serratia spp), 3 spesies kokus Gram positif (S. saphrophyticus, S. epidermidis, dan $M$. luteus), dan 1 spesies batang Gram positif (Bacillus spp). Bakteri kontaminan yang didapat pada unit HD RS B terdiri dari Pseudomonas spp., Y. Pseudotuberculosis, dan Bacillus spp. Jenis spesies yang ditemukan pada pertemuan ini berbeda dengan temuan di Brazil pada tahun 2009 oleh Montanari L.B. dkk. 4 spesiesyang ditemukan sebagai kontaminan adalah $K$. pneumoniae, $Y$. pseudotuberculosis, M. luteus, dan Bacillus spp. ${ }^{3}$

Seluruh spesies bakteri yang ditemukan pada penelitian ini bersifat saprofit, bukan patogen, namun jika melewati membran dialiser dan masuk ke dalam tubuh pasien HD yang imunokompromais dapat menimbulkan bakteremia dan menimbulkan infeksi yang berat seperti peritonitis, meningitis, hingga abses otak..$^{1,3}$

Keterbatasan pada penelitian ini adalah tidak dilakukannya pendataan mengenai faktor-faktor yang dapat mempengaruhi kualitas air RO secara mikrobiologi, tidak dilakukan pendataan dan pencarian korelasi antara tingkat kontaminasi dengan respon inflamasi yang terdapat pada pasien 
$\mathrm{HD}$, penelitian ini hanya dilakukan pada unit HD di Kota Bandung sehingga tidak mewakili data kualitas air RO pada pelayanan HD di Indonesia.

Berdasarkan hasil penelitian, disimpulkan bahwa kualitas air RO pada sarana pelayanan HD di Kota Bandung masih perlu ditingkatkan. Kualitas air RO pada unit HD di rumah sakit A perlu segera diperbaiki sebagai bagian dari keselamatan pasien (patient safety), sedangkan untuk sarana HD di rumah sakit B sudah baik dan diupayakan untuk mempertahankan kualitas air RO yang sudah baik. Perlu dilakukan penelitian lebih lanjut tentang faktor-faktor yang dapat mempengaruhi kualitas air RO secara mikrobiologi, korelasi antara peningkatan kualitas air RO dengan penekanan pertumbuhan bakteri kontaminan, dan penelitian mengenai hubungan antara kualitas air RO dengan kejadian inflamasi kronis pada pasien HD kronik di unit HD tersebut. Evaluasi kualitas air RO hendaknya menjadi program rutin pada seluruh unit HD di Indonesia.

\section{Ucapan Terima Kasih}

Terimakasih kepada Direksi kedua RS yang memiliki unit $\mathrm{HD}$ atas ijin yang diberikan dalam melakukan penelitian ini. Penelitian ini mendapat dukungan dari Dana DIPA Unpad melalui Hibah Kompetitif Tahun 2013.

\section{Daftar Pustaka}

1. Ward RA. Dialysis Water as a Determinant of the Adequacy of Dialysis. Semin Nephrol. 2005. 25:102-11.

2. ISO 11663:2014, Quality of dialysis fluid for haemodialysis and related therapies.

3. Montanari LB, Sartori FG, Cardoso MJO, Varo SD, Pires RH, Leite CQF, et al. Microbiological Contamination of a Hemodialysis Center Water Distribution System, Rev. Inst. Med. Trop. S. Paulo, 2009. 51(1): 37-43.

4. Lima JRO, Marques SG, Gonçalves AG, Filho NS, Nunes PC, Silva HS, et al. Microbiological Analysis of Water from Hemodialysis Services in São Luís, Maranhão, Brazil., Braz J Microbiol, 2005. 36: 103-8.

5. Cappelli G, Sereni L, Scialoja MG, Morselli M, Perrone S, Ciuffreda A, et al. Effects of Biofilm Formation on Haemodialysis Monitor Disinfection, Nephrol Dial Transplant, 2003. 18: 2105-11.

6. Weber V, Linsberger I, Rossmanith E, Weber C, Falkenhagen D. Pyrogen Transfer across High- and Low-flux Hemodialysis Membranes. Artif Organs, 2004. 28(2):21017.

7. Glorieux G, Neirynck N, Veys N, Vanholder R. Dialysis water and fluid purity: more tan endotoxin. Nephrol Dial Transplant, 2012. 0: $1-12$.

8. Santoro A, Mancini E. Cardiac effects of chronic inflammation in dialysis patients, Nephrol Dial Transplant, 2002, 17 [Suppl 8]: $10-15$.

9. Amore A, Coppo R. Immunological basis of inflammation in dialysis. Nephrol Dial Transplant, 2002, 17 [Suppl 8]: 16-24.

10. Jofre R, Rodriguez-Benitez P, Lopez-Gomez JM, Perez-Garcia R. Inflammatory Syndrome in Patients on Hemodialysis, J Am Soc Nephrol, 2006, 17: S274-80.

11. El-Banawy S, Emara FES, Kandil MH, Khalil ES, Maharem D. Atherosclerosis in Hemodialysis Patients: Relation To Chronic Inflammation and Endothelial Dysfunction. JMRI, 2007 28(2): 131-41

12. Raafat M, Metwaly A, Khalik AA, Abu-Zikri N, Madkour M, Hussein N. Inflammatory and Nutritional Biomarkers: Role as Non -Traditional Risk Factors for Cardiovascular Morbidity in Patients with Chronic Kidney Disease. Life Sci J 2012;9(2):1109-16.

13. Rafiean-Kopaie $M$, Nasri $H$. Impact of inflammation on anemia of hemodialysis patients who were under treatment of recombinant human erythropoietin. J Ren Inj Prev. 2013; 2(3): 93-5.

14. Rao P, Reddy GC, Kanagasabapathy AS. Malnutrition-Inflamation-Atherosclerosis Syndrome in Chronic Kidney Disease, Indian J Clin Biochem, 2008/23 (3) 209-17.

15. U.S. Renal Data System, USRDS 2013 Annual Data Report: Atlas of Chronic Kidney Disease and End-Stage Renal Disease in the United States, National Institutes of Health, National Institute of Diabetes and Digestive and Kidney Diseases, Bethesda, MD, 2013.

16. Pernefri, 4th Report of Indonesian Renal Registry 2011, Indonesian Renal Registry, 2011.

17. Undang-undang No 24 Tahun 2011 tentang Badan Penyelenggara Jaminan Sosial.

18. Northwest Renal Network, Monitoring Your Dialysis Water Treatment System, June 2005.

19. Black G, Jacquelyn G. Microbiology: principles and explorations, edisi ke 8. John Wiley \& Sons, Inc.2012,6:151.

20. Fenton MJ, Golenbock DT. LPS-binding proteins and receptors, J. Leukoc. Biol. 1998: 64: 25-32. 